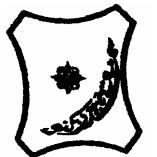

Bayero Journal of Pure and Applied Sciences, 4(1): 79 - 82

Received: October, 2010

Accepted: May, 2011

ISSN 2006 - 6996

\title{
SYNERGISTIC ACTIVITY OF METHANOLIC EXTRACT OF ADENIUM OBESUM (APOCYNACEAE) STEM-BARK AND OXYTETRACYCLINE AGAINST SOME CLINICAL BACTERIAL ISOLATES
}

\author{
A Tijjani ${ }^{1} *$, MS Sallau ${ }^{2}$ and I Sunusi ${ }^{3}$ \\ ${ }^{1}$ Ahmadu Bello University, School of Basic and Remedial Studies, Funtua, Nigeria \\ ${ }^{2}$ Department of Chemistry, Ahmadu Bello University, Zaria, Nigeria \\ ${ }^{3}$ Department of Pre-ND and General Studies, School of Technology, Kano State Polytechnic, Kano, Nigeria \\ *Correspondence author:tjjnahmad@yahoo.com
}

\begin{abstract}
Adenium obesum plant (stem-bark) was collected, identified, air-dried, ground and extracted using hot-continuous extraction method. Standard phytochemical tests and antimicrobial tests using Kirby and Bauer techniques were adopted for the phytochemical screening and antimicrobial tests of the plant stem-bark methanolic extract respectively. The MIC of methanolic extract in combination with oxytetracycline using 8 different clinical bacterial isolates, both Gram positive and Gram negative, was found to be around $(62.5 \mu \mathrm{g} / \mathrm{ml}$ to $1250 \mu \mathrm{g} / \mathrm{ml}) . I n$ all, $87.5 \%$ showed synergistic activity against 8 different bacterial isolates, both gram positive and gram negative species. The highest synergistic activity was attained against Streptococcus pyogenes .Phytochemical examination of the extract revealed the presence of alkaloids, steroids, saponins, glycosides, anthraquinones, tannins and flavonoids. This result indicated strong antibacterial activity of the methanolic extract in combination with oxytetracycline against the pathogenic bacterial isolates.
\end{abstract}

Keywords: synergism, methanol, Adenium obesum, oxytetracycline, extract, clinical isolates

\section{INTRODUCTION}

Herbal medicine represents one of the most important fields of traditional medicine all over the world. To promote the proper use of herbal medicine and determine their potential as source of new drugs, it is essential to study medicinal plants which have folklore reputation in more intensified way (Parekh and Chanda, 2007).

Adenium obesum (Apocynaceae) is a plant found in Northern Nigeria, commonly known as 'karya' in hausa (Dalziel, 1956).The English name is Desert rose. It is a Succulent shrub or small tree, up to (4-6) $\mathrm{m}$ tall, sometimes with a fleshy taproot; stem swollen at base up to (1-2) $\mathrm{m}$ in diameter; bark pale greyishgreen, grey or brown, smooth, with sticky, clear or white latex; branchlets glabrescent, pubescent at apex. Leaves arranged spirally, clustered at the end of branchlets, simple; stipules minute or absent; petiole up to $4 \mathrm{~mm}$ long; blade linear to obovate, 3$12(-17) \mathrm{cm} \times 0.2-6 \mathrm{~cm}$, base cuneate, apex acute to rounded or emarginate, entire, slightly glaucous, dull green or pale green, leathery, pinnately veined with distinct or indistinct lateral veins (Rowley, 1983).

The plant is important in traditional medicine. In the Sahel, a decoction from the roots, alone or in combination with other plants, is used to treat venereal diseases; a root or bark extract is used as a bath or lotion to treat skin diseases and to kill lice, while latex is applied to treat septic wounds( Neuwinger, 2000). In Somalia, a root decoction as nose drops is prescribed for rhinitis( Neuwinger, 2000). In northern Kenya, latex is rubbed on the head against lice and powdered stems are applied to kill skin parasites of camels and cattle( Neuwinger, 2000). The bark is chewed as an abortifacient ( Neuwinger, 2000).

Since some bacteria are resistant to many antibiotics, there is a need to test for antibiotic-plant's extract combined activity (synergistic activity).This could provide a way out for bacterial resistant diseases. The synergistic effect from the association of antibiotic with plant extracts against resistant bacteria leads to new choices for the treatment of infectious diseases. This effect enables the use of the respective antibiotic when it is no longer effective by itself during therapeutic treatment. Therefore, the present study was undertaken for the first time to investigate synergistic activity of methanolic extract of Adenium obesum stem-bark with oxytetracycline.

The objective of this study was to formulate new, cost effective anti-microbial combination for multidrug resistant diseases based on the synergistic activity of oxytetracycline and methanolic extract of Adenium obesum (Apocynaceae), a tradomedicinal plant common in Nigeria. The synergistic activity was verified using Kirby and Bauer techniques. 


\section{MATERIALS AND METHODS} Collection and Preparation of Plant Material

The stem-bark of Adenium obesum was collected from Samaru-Zaria, Kaduna State of Nigeria. It was confirmed and authenticated at the Herbarium, Biological Sciences Department, Ahmadu Bello University-Zaria where a voucher specimen number 1836 was deposited there. The bark was air dried and ground into powdered form using a porcelain mortar and pestle. It was then preserved well in polyethene bag and stored in a desiccator before subsequent experiments.

\section{Extraction}

The powered stem-bark of Adenium obesum $(500 \mathrm{~g})$ were packed into a thimble and placed inside a soxhlet extractor and extracted exhaustively and respectively with petroleum spirit $(60-80){ }^{\circ} \mathrm{C}$ and methanol (1 litre each). The extracts were concentrated in vacuo at $40{ }^{\circ} \mathrm{C}$ using rotary evaporator, after which the crude extracts were obtained from the solvents (Harbone, 1994).

\section{Phytochemical screening}

The petroleum and methanolic extracts of the stembark of Adenium obesum were subjected to preliminary phytochemical tests to detect the presence of alkaloids, steroids, saponins, glycosides, anthraquinones, tannins,terpenoids, coumarins, carbohydrates and flavonoids using standard techniques (Trease and Evans, 1984; Trease and Evans 1989; Sofowora ,1993).

\section{Test organisms}

The clinical bacterial isolates used are: Escherichia coli, Klebsiella pneumoniae, Pseudomonas aeruginosa, Salmonella typhi, Bacillus subtilis, Streptococcus pyogenes,Staphylococcus aureus and Corynebacterium ulcerans.These were obtained from the Department of Medical Microbiology, Ahmadu Bello University Teaching Hospital (ABUTH) ZariaNigeria. The bacterial isolates were maintained on nutrient agar and sub-cultured every three days. An inoculum of each bacterial strain was suspended in 5 $\mathrm{ml}$ of Mueller Hinton broth (MHB) and incubated overnight at $37{ }^{\circ} \mathrm{C}$. The overnight cultures were diluted with Normal Saline and adjusted to give a concentration of bacterial cells equivalent to a McFarland 0.5 standard prior to the bacterial testing (Samie et al., 2005).

\section{Synergistic activity}

The synergistic activity study was achieved by combining the extract with the antibiotic, oxytetracycline, using disc diffusion technique (Kirby and Bauer technique). Methanolic plant extract of Adenium obesum, $125 \mu \mathrm{g} / \mathrm{ml}$, was used in combination with oxytetracycline $62.5 \mu \mathrm{g} / \mathrm{ml}$. The distance between the discs was maintained as standard of about $0.8 \mathrm{~cm}$ then incubated at the standard conditions for 24 hours at $37^{\circ} \mathrm{C}$ and the zone diameters was measured in the second day using a ruler (Betoni et al., 2006).

\section{Minimum inhibitory concentration [MIC]}

A series of culture tubes (microdilution assays) (Ferreira et al., 2003) were prepared all containing the same volume of medium inoculated with test microorganisms. The lowest concentration of sample at which the subculture from test dilution yielded no viable organisms was recorded as minimum bactericidal concentration (Nazaruk and Jakoniuk, 2005). Decreasing concentration of drug was added to the tubes usually a step wise dilution (two fold serial dilutions) was used starting from highest to lowest concentrations $(20 \mathrm{mg} / \mathrm{ml}, 10 \mathrm{mg} / \mathrm{ml}, 5 \mathrm{mg} / \mathrm{ml}, 2.5$ $\mathrm{mg} / \mathrm{ml}$ and $1.25 \mathrm{mg} / \mathrm{ml})$. One tube was left without drug to serve as positive control and other without drug and inoculum to serve as negative control. The cultures were incubated at a temperature optimal for growth of the test organism and a period of time sufficient for growth for at least 10-15 generators (usually 24 hours for bacteria at $37^{\circ} \mathrm{C}$ ). The tubes were inspected visually to determine the growth of organisms by the presence of turbidity and the tubes in which antibiotic is present in minimum concentration sufficient to inhibit the microbial growth which remains clear was noted as MIC of the extract. In experimental terms MIC is the concentration of the drug present in the last clear tube, which is the tube having the lowest antibiotic concentration in which growth is not observed.

The minimum inhibitory concentration was determined for oxytetracycline alone,then for the stem-bark extract of Adenium obesum and finally combination of oxytetracycline and methanolic stem-bark extract of Adenium obesum (1:1).

\section{RESULTS}

Preliminary phytochemical screening: The preliminary phytochemical screening revealed the presence of alkaloids, steroids, saponins, glycosides, anthraquinones, tannins and flavonoids. However, coumarins were absent in the extract (Table 1).

The MIC results for oxytetracycline alone, stem-bark extract of Adenium obesum only and combination of oxytetracycline and methanolic stem-bark extract of Adenium obesum (1:1) were presented in Table 2. The MIC values were found to be less with oxytetracycline alone and it was found to be still lesser with the methanolic extract of Adenium obesum . However, the MIC was found to be the least with combination of oxytetracycline and methanolic stembark extract of Adenium obesum. Moreover, the therapeutic efficacy was found to be higher even in low concentration.

This clearly exhibits the advantage of the combination of oxytetracycline and methanolic extract of Adenium obesum over the other two individual forms coupled with enhanced synergistic activity.

In the present study, the antimicrobial activities of stem-bark methanolic extract of Adenium obesum on various strains were confirmed and synergism was possible with the antimicrobial drug tested. Oxytetracycline presented good synergism with methanolic extract of Adenium obesum. 
In these findings, Streptococcus pyogenes shows higher sensivity to synergistic combination indicated by higher zone diameter (37 mm), lowest synergistic effect was observed against Pseudomonas aeruginosa $(24 \mathrm{~mm})$ and Salmonella typhi (24 mm). No synergistic activity was observed against Klebsiella pneumoniae.Out of 8 different bacteria, both Gram positive and Gram negative tested, $87.5 \%$ were sensitve to synergistic activity of the drug and the extract (Table 3).

Table 1: Phytochemical constituents of Adenium obesum (stem-bark) extract

\begin{tabular}{lcc}
\hline S/No. & Phytochemicals & Results \\
\hline 1 & Carbohydrates & methanolic extract \\
2 & Steroids & + \\
3 & Terpenoids & + \\
4 & Saponins & + \\
5 & Tannins & + \\
6 & Anthraquinones & + \\
7 & Cardiac glycosides & + \\
8 & Alkaloids & + \\
9 & Coumarins & - \\
\hline
\end{tabular}

key: +/- = presence, absence of phytochemical tested

Table 2: Minimum inhibitory concentration of Adenium obesum (stem-bark) extract

\begin{tabular}{llll}
\hline Test organisms & MIC of O $(\mu \mathrm{g} / \mathrm{ml})$ & MIC of E $(\mu \mathrm{g} / \mathrm{ml})$ & MIC of EO $(1: 1)(\mu \mathrm{g} / \mathrm{ml})$ \\
\hline Escherichia coli & 125 & 500 & 62.5 \\
Klebsiella pneumonia & 1500 & 2000 & 1500 \\
Pseudomonas aeruginosa & 500 & 1000 & 125 \\
Salmonella typhi & 1000 & 1000 & 500 \\
Bacillus subtilis & 500 & 1000 & 62.5 \\
Streptococcus pyogenes & 500 & 500 & 125 \\
Staphylococcus aureus & 1250 & 1250 & 125 \\
Corynebacterium ulcerans & 1000 & 1250 & 500 \\
\hline
\end{tabular}

Key: $\mathrm{O}=$ Oxytetracycline, $\mathrm{E}=$ Methanolic extract of Adenium obesum, EO= Methanolic extract of Adenium obesum + oxytetracycline.

Table 3: Synergistic activity of methanolic extract of Adenium obesum (Stem-bark)

\begin{tabular}{llcc}
\hline Test organisms & \multicolumn{3}{c}{ Zone of inhibition( mm) } \\
\cline { 2 - 4 } & 0 & E & EO \\
\hline & & 20 & 27 \\
Escherichia coli & 25 & 00 & 00 \\
Klebsiella pneumonia & 06 & 18 & 24 \\
Pseudomonas aeruginosa & 20 & 19 & 24 \\
Salmonella typhi & 17 & 25 & 32 \\
Bacillus subtilis & 27 & 26 & 30 \\
Streptococcus pyogenes & 29 & 26 & 26 \\
Staphylococcus aureus & 26 & 19 & 21
\end{tabular}

Key:O= Oxytetracycline, E = Methanolic extract of Adenium obesum, EO= Methanolic extract of Adenium obesum + oxytetracycline. Disc size $=06 \mathrm{~mm}$

\section{DISCUSSION}

The results of the synergism study depicted that the Gsram positive bacteria (Bacillus subtilis, Streptococcus pyogenes, Staphylococcus aureus and Corynebacterium ulcerans) were those that exhibited higher sensivity to synergistic effect than the Gram negative ones (Escherichia coli, Klebsiella pneumonia, Pseudomonas aeruginos and Salmonella typhi).This is because gram-negative bacteria were reported to have higher intrinsic resistance to most antimicrobial agents (Ndukwe et al., 2005).In general, the plant- drug combination is synergistically very active against the microorganisms. This high activity could be ascribed to the presence of the secondary metabolites available in the plant.

There are tannins which are reported to have various physiological effects like anti-irritant, antisecretolytic, antiphlogistic, antimicrobial and antiparasitic effects. Phytotherapeutically tannin-containing plants are used to treat nonspecific diarrhoea, inflammations of mouth and throat and slightly injured skins (Westendarp, 2006; Trease and Evans, 2000). 
Steroids are also there,which are important drugs used as hypotensives, cardiac depressants, sedatives and anti-dysenteric agents (Abdul,1990) while glycosides which are used as laxative and carthatic drugs were confirmed. Alkaloids that act as antimalarial, anti-amoebic agents, astringents were present (Abdul, 1990).

The test organisms used in this study are associated with various forms of human infections. From a clinical point of view, Streptococcus pyogenes cause a wide spectrum of diseases, including tonsillitis, erysipelas, impetigo, scarlet fever, rheumatic fever, septicaemia and acute glomerulonephritis (Greenwood et al,1992). Escherichia coli causes septicemias and can infect the gall bladder, meninges, surgical wounds, skin lesions and the lungs especially in debilitate and immunodeficient patients (Black, 1996). Infection caused by Salmonella typhi is a serious public health problem in developing countries and represents a

\section{REFERENCES}

Abdul .G. (1990). Introduction to Pharmacognosy $1^{\text {st }}$ Edition Ahmadu Bello University, Press Ltd, Zaria -Nigeria pp 187-197.

Betoni JEC, Mantouani RP, Barbosa LN, Stasi LCD and Fernander (2006). A Synergism between plant extract and antimicrobial drugs used on Staphylococcus aureus diseases. Mem Inst Oswaldo Cruz, Rio De Janerio; 101: 387-90.

Black. J.G. (1996). Microbiology. Principles and application. New York, Prentice Hall. p 260.

Dalziel. J. M. (1956) . The Useful Plants of West Tropical Africa.Crown Agents, London. p 365.

Ferreira MJU, Ascenso JR, Valdeira L, Duarte A, Frade JP, Freitas G (2003). Evaluation of antiviral and antimicrobial activities of triterpenes isolated from Euphorbia segetalis. Nat Prod $R$ es e arch; $17: 375-80$

Greenwood D. Richard.C.B.S. and John.F.P (1992). Medical Microbiology. A Guide to microbial Infections, Pathogenesis, Immunity, Laboratory Diagnosis and Control.Longman Group Ltd Hong Kong. p 211.

Harbone N.V. (1994). Phytochemical methods: $A$ guide to modern techniques of plant analysis, 2nd Edition, Chapman and Hall London. p 425.

Mastroeni P (2002). Immunity to systemic salmonella infections. Curr Mol Med:; 2: 393-406.

Nazaruk J, Jakoniuk P (2005). Flavonoid composition and antimicrobial activity of Crisium rivulare (jacq) flowers. J Ethnopharmacol; 102: 20812.

Ndukwe, K.C., Okeke, I.N., Lamikanra, A., Adesina, S.K. and Aboderin, O.(2005). Antibacterial constant concern for the food industry (Mastroeni, 2002). The demonstration of activity against both Gram negative and Gram positive bacteria is an indication that the plant can be a source of bioactive substances that could possess broad spectrum of activity.

Thus, there is increasing need for researchers to investigate the synergistic capacity of plants or other natural products, independent of the antimicrobial activity they have. The results of the present study seem to be promising and may enhance the natural products uses, showing the potentiality of Adenium obesum in the treatment of various infectious diseases caused by bacteria. It also indicates the need for understanding of synergism mechanism is fundamental to development of pharmacological agents to treat diseases by various bacteria using medicinal plants.

activity of aqueous extracts of selected chewing sticks. J. Contemp. Dental Pract., 6(3):86-94.

Neuwinger, H.D ( 2000). African traditional medicine: a dictionary of plant use and applications. Medpharm Scientific, Stuttgart, Germany. $p$ 589.

Parekh, J. and Chanda S ( 2007). In vitro antibacterial activity of the crude methanol extract of Woodfordi Fruticosa kurz. flower (lythraceae). Brazilian J.Microbiol., 38: 204207.

Rowley, G.D. (1983). The Adenium and Pachypodium handbook. Smart \& Co. Ltd., Brackley, United Kingdom. P 95.

Samie, A., Obi, C.L., Bessong, P.O. and Namrita, L. (2005). Activity profiles of fourteen selected medicinal plants from Venda Communities in South Africa against fifteen clinical Bacterial species. Afr. J. Biotech., 4(12):1443-1451.

Sofowora A, (1993). Medicinal plants and Traditional medicine in Africa. Spectrum Books Ltd, Ibadan, Nigeria. p 289.

Trease G.E and C. W Evans C. W (1984). Pharmacognosy. 12th Edition. Balliere Tindall, London. p 257.

Trease G.E. and Evans, W.C. (1989) Pharmacognosy. $13^{\text {th }}$ (ed). ELBS/Bailliere Tindall, London. Pp. 345-6, 535-6, 772-3.

Trease G.E. and Evans W.C (2000). Pharmacognosy.14 $4^{\text {th }}$ Edition Harcourt Publishers Limited London

Westendarp H. (2006). Effects of tannins in animal nutrition. Dtsch Tierarztl Wochenschr 113(7): 264-268 